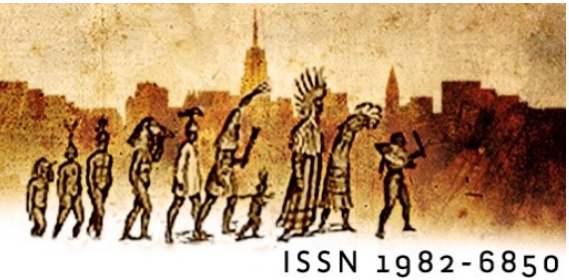

\title{
Augusto de Campos: 90 anos de Poesia [para o Planeta]
}

Omar Khouri

O artista tem um único compromisso com a Humanidade: dar o melhor de si. Dr. Ângelo Monaqueu, em sala-de-aula

Discorrer sobre Augusto de Campos [Augusto Luís Browne de Campos, o mais amado dentre os poetas concretos], hoje, é o mesmo que indagar o como é possível (muito embora raro, raríssimo) chegar aos 90 anos de idade em plena forma e produzindo poemas, textos críticos e traduções-recriações poéticas de maneira surpreendente [e publicando-os], como vem fazendo esse criador [esse produtor de linguagem, esse "designer da linguagem"], desde fins dos anos 1940, mas principalmente a partir dos '50 [o poeta nasceu em 14 de fevereiro de 1931, na cidade de São Paulo, onde cresceu e teve a sua formação, em todos os níveis, e publicou seu $1^{\circ}$ livro : O rei menos o reino, 1951 - fico a imaginar como seria o ambiente naquela casa, com altíssimo índice de inteligência e talento por metro quadrado: a casa dos Browne de Campos, na Pauliceia]. Concreto histórico [integrou o trio fundador do Grupo Noigandres (1952)], é considerado um inventor, ou melhor, co-inventor de um modo que mexeu com as estruturas do fazer poético sendo que, no Brasil, esse movimento entrou como um divisor de águas: o antes e o depois da Poesia Concreta [esta penetrou até no modus operandi de veteranos, mesmo que à revelia, deixando suas marcas]. Mesmo pertencendo a um grupo de vanguarda e seguindo procedimentos firmados por seus integrantes [mormente na dita "fase ortodoxa", anos de 1950], a poesia de Augusto de Campos sempre apresentou peculiaridades que a fizeram única, desde que, em 1953, elaborou a série Poetamenos, num diálogo íntimo com a música de Anton Webern [a intersemioticidade detectada naqueles seis 
poemas acabaria sendo uma das principais características do Concretismo poético. Para essa série de poemas coloridos, poder-se-ia falar em 'tradução intersemiótica', conceito este colocado, depois, por Roman Jakobson]: considerado $01^{\circ}$ conjunto sistemático de poemas concretos [tais poemas já colocam o moço de 22 anos de idade no topo da História da Poesia mundial]. Em 1955, propôs o nome Poesia Concreta para aquela que estava fazendo, juntamente com seu irmão Haroldo e com Décio Pignatari, o que contou com a concordância de Eugen Gomringer - poeta suíçoboliviano experimentador e que era secretário de Max Bill na Escola Superior da Forma em Ulm, Alemanha, e com quem Décio Pignatari havia entrado em contato. $E$ o movimento tornou-se internacional [criando, no Brasil, desafetos duradouros e alguns simpatizantes]. O percurso poético de Augusto de Campos é dos mais admiráveis, do pós-Segunda Guerra à atualidade, passando por fases distintas [peças seminais como eis os amantes, dias dias dias, lygia fingers, cidade, luxo, viva vaia, o pulsar, memos... dão uma medida da evolução da Poesia de Augusto de Campos e mais a infopoesia, território em que produziu belos poemas], mas mantendo a coerência dentro daquilo que o vinha caracterizando: a parcimônia, a originalidade e o rigor, dentro do universo "verbivocovisual". Alguns de seus poemas já adentraram a corrente sanguínea da sociedade e fazem a alegria de tantos quantos vêm a ser aficionados da arte da palavra, por excelência, da Arte de Augusto de Campos, podese dizer. Nessas décadas todas de intensa produção poética - peças densas em relativa pequena quantidade - o poeta praticou uma crítica interdisciplinar, de um aclaramento ímpar [amor/sensibilidade, conhecimento e rigor norteando seus passos, na abordagem dos poetas: de Arnaut Daniel a John Donne, de Mallarmé a Ezra Pound e Cummings ..., de músicos, como John Cage (e adentrando o território da música popular mais elaborada), de artistas plásticos como Marcel Duchamp e tantos outros, como os artistas concretos, que operaram a partir de São Paulo, a quem dedicou peças poéticas lapidares: quadros-poemas]. Versando principalmente sobre criadoresinventores de época recente, ou não tão recente assim, resgatou valores do passado que haviam sido mal lidos ou nem sequer propriamente lidos [Oswald de Andrade, Sousândrade, Kilkerry...]. Trabalhou em textos que considerava fundamentais da poesia universal, praticando uma tradução criativa (tradução-arte, como tem dito), 
com o propósito de formar um conjunto significativo, em Português, da melhor poesia produzida no mundo [e esta foi uma das frentes em que atuaram os poetas concretos do Brasil - um esforço conjunto na elaboração de um Paideuma]. Houve quem dissesse, em Portugal, ser Augusto de Campos o maior tradutor de textos poéticos para a Língua Portuguesa, de todos os tempos [disponibilizou, em sua grandeza poética, peças de Arnaut Daniel, John Donne, Mallarmé, Laforgue, Emily Dickinson, Lewis Carroll, Maiakóvski, Pound, Cummings...]. E, muito embora não tenha optado pela Docência, como alguns companheiros chegaram a fazer, Augusto de Campos desempenhou esse papel didático em muitas conversas que tinha, com gentes de todas as idades, nas incontáveis vezes em que recebeu, em sua casa, com sua esposa Lygia de Azeredo Campos, pessoas interessadas em arte experimental [a casa da Rua Bocaina-Perdizes-SP (em verdade, um apartamento) teve tanta ou mais importância para a poesia brasileira e as artes em geral que as de Paulo Prado, de Mário de Andrade, de Tarsila do Amaral e Oswald de Andrade e de Dona Olívia Guedes Penteado, e por muito mais tempo]. Não há hoje, no Planeta, dentre os viventes, alguém com um conjunto de obra tão significativo como o que produziu, em cerca de sete décadas, Augusto de Campos. E esse reconhecimento vem vindo aos poucos, a lentos e firmes passos, de fora do País e também de dentro. Basta entrar em contato com sua obra para se ver quanta riqueza ela contém em termos de invenção/informação. João Cabral de Melo Neto - poeta mais que consagrado e com relação ao qual havia [e há] como que uma unanimidade no Brasil - chegou a dizer, em diversas ocasiões, que o legado da Poesia Concreta havia sido mais importante para o Brasil que o do Modernismo de 22 [certamente, referindo-se à quebra de estruturas, portanto, às inovações]. E, quando João Cabral era estimulado a citar poetas mais jovens, ele citava Augusto de Campos. Este é um dos grandes criadores do século XX, num confronto internacional (como gostava de dizer Décio Pignatari), que adentrou, com pleno vigor, o Terceiro Milênio. Salve Augusto de Campos, [Multiartista-] Poeta!

\footnotetext{
${ }^{i}$ Nascido em Pirajuí, em 1948, é graduado em História pela USP, Mestre e Doutor em Comunicação e Semiótica pela PUC-SP. Livre-docente em Teoria e Crítica da Arte pela UNESP, Pós-Doutor pela Universidade de Lisboa. Professor-adjunto na UNESP. Poeta, artista gráfico, editor, curador, participou de exposições intersemióticas na Holanda, Estados Unidos, Portugal, Itália. Co-editor da "Nomuque" desde 1974 . 